DOI dx.doi.org/10.24866/7444-4707-6/102-113

\author{
А.В. Брикманс, О.В. Нестерова, \\ В.А. Семаль, Н.А. Рыбачук
}

\title{
КАРБОНАТНЫЕ ПОЧВЫ ПРИРОДНО-ТЕХНОГЕННОЙ ПОЧВЕННОЙ КАТЕНЫ «ГОЛУБИНОГОРСКОЙ» ЮГА ДАЛЬНЕГО ВОСТОКА
}

Территория юга Дальнего Востока России является своеобразной зоной перехода от континента к океану, подвергающейся интенсивному воздействию Тихого океана. Взаимодействие континента и океана, проявляющееся в основном через климатические факторы, лежит в основе формирования многих природных процессов, накладывая отпечаток на направленность процессов почвообразования. В результате формируется весьма сложный по составу и структуре почвенный покров $[8,9,12]$. При изучении почв естественных и антропогенных ландшафтов особую роль приобретают исследования как их физико-механических свойств с точки зрения опорной механической системы, так и физико-химических, как питательного субстрата. В связи с этим изучение физической прочности и устойчивости почв к механическим воздействиям в условиях муссонного климата становится актуальным.

В почвенном покрове Приморского края, наряду с широко распространенными буроземами типичными, определенное место занимают почвы, развитые на карбонатных горных породах: буроземы темные и коричневые почвы. Они отличаются своеобразием свойств, связанных со спецификой почвообразования [6,7]. Изучение генетических особенностей и свойств указанных почв необходимо для решения вопросов их генезиса.

Проведены исследования основных типов почв природно-техногенной почвенной катены «Голубиногорская». Природно-техногенная почвенная катена «Голубиногорская» приурочена к территории, относящейся к ЮжноПриморской зоне Западно-Приморской области. В этой зоне широко распространены карбонатные породы, прорванные гранитами, цементные известняки, а также обилие крупных массивов сравнительно чистых известняков [4].

Целью исследования являлось изучение почв, сформировавшихся на карбонатных горных породах. В задачи входило изучение условий форми- 
рования и морфологических особенностей почв по компонентам катены, исследование физико-механических и физико-химических свойства почв, установление классификационного положения почв.

Природно-техногенная почвенная катена «Голубиногорская» заложена в пределах Голубиногорского месторождения известняков, находящегося на правом берегу р. Артёмовка, в 5 км ниже с. Многоудобное Приморского края. Сложена Чандалазской свитой (Майхинская подсвита) верхнепермского возраста, местами прорванной гранитами.

При выполнении работы применялись сравнительно-географический, профильный, морфологический, физико-химический методы исследований общепринятые в почвоведении.

Гигроскопическую влажность, гранулометрический и микроагрегатный состав определяли по [10]. Плотность твердой фазы почв - по [2]; противоэрозионной стойкость - по $[13,14,15]$; содержание углерода по методу Тюрина [1]. Оценка качества структуры почв, микроагрегатной устойчивости и их противоэрозионных свойств по результатам гранулометрического и микроагрегатного состава произведена по Н.А. Качинскому (фактор дисперсности) [10]; противоэрозионная стойкость определена по А.Д. Воронину и М.С. Кузнецову [3] с использованием коэффициента дисперсности Н.А. Качинского [10] и гранулометрического показателя структурности по А.Ф. Вадюниной и 3.А. Корчагиной [2]. Название почв дано по «Классификации почв» [11].

Содержание карбонатов в земной коре составляет около 3,5 \%, в педосфере - в среднем около 1,3 \%. Основная часть карбонатов земной коры сосредоточена в осадочных породах, которые являются главным поставщиком углекислоты в грунтовые воды и почвы. Присутствие карбонатов определяют по вскипанию с 10 \% раствором соляной кислоты. Интенсивность вскипания (потрескивание, отдельные пузырьки, сплошная пенка) указывают на обилие карбонатов. Тест используется только для диффузных форм вторичных карбонатов. Если появляется пенка при обработке соляной кислотой, то содержание эквивалента карбоната кальция составляет $15 \%$ или более. Почвы, в которых происходит значительная аккумуляция карбоната кальция, называются кальцисоли (Calcisols). Впервые термин был использован в 1952 году в США для почв на высококарбонатных породах в аридных 
и семиаридных районах. Морфологические особенности кальцисолей зависят от форм аккумуляции карбонатов. Почвы с горизонтом кальцик отличаются палево-бурой окраской, ореховатой или глыбисто-ореховатой, реже плитчатой структурой, плотным сложением, имеют более высокие показатели плотности по сравнению с соседними некарбонатными горизонтами. В пылеватых кальцисолях на поверхности часто образуется корка. Кальцисоли всегда насыщены основаниями, кислотность располагается в нейтральнойслабощелочной области, содержание органического вещества низкое. Присутствие горизонта кальцик может быть обнаружено также по светлой окраске почвы - беловатой, розовой до красноватой или серой и низкой пористости. Межагрегатная пористость в горизонте кальцик ниже в вышележащем, иногда и в нижележащем горизонтах.

Характерна катенарная дифференциация видов карбонатных новообразований по склону: от пропиточных форм в верхних частях к отдельным сегрегациям и сплошным прослоям в нижних. Таким образом происходит нарастание концентрации карбонатов вниз по катене. По катене изменяется и характер верхней границы горизонта кальцик - она становится все более резкой вниз по катене, а разница в содержании карбонатов между горизонтом кальцик и вышележащим возрастает в том же направлении. Осаждение карбонатов происходит в основном в верхней части горизонта кальцик. С течением времени строение горизонта кальцик постепенно изменяется. Пропитка почвенной массы, псевдомицелий, кутаны, пятна, мягкие или плотные стяжения, прожилки, неслоистые прослойки и корочки сменяются сплошным слоями, часто сцементированными или сплошной очень плотной карбонатной корой.

Первый компонент катены - почвы: буроземы темные остаточнокарбонатные крайне мелкие средне скелетные, развитые на элювии мраморизированных известняков.

Разрез 1 заложен на вершине сопки. Растительность на представлена изреженным лиственным лесом с обнаженными, слабо заросшими участками, возникшими вследствие антропогенного воздействия (добыча известняка). В древесном ярусе преобладают Quercus mongolica (дуб монгольский) и Salix caprea (ива козья). Из кустарников отмечены Corylus heterophylla (лещина разнолистная), Lespedeza bicolor (леспедеца двуцветная). Среди травянистых растений преобладают многолетние злаки. Морфологический профиль почв состоит из генетических горизонтов. 
A0 (0 - 0,5 см) - дернина рыхлая, масса вскипает от $10 \% \mathrm{HCl}$.

$\mathrm{AU}(0,5$ - 10 см) - коричневато-серый, сухой, зернисто-мелкокомковатый, среднесуглинистый, рыхлый, пронизан корнями диаметром от 1 до 15 мм, со сформировавшимися карбонатными конкрециями, присутствуют свежие и в разной степени разрушенные обломки карбонатных пород (масса вскипает от $10 \% \mathrm{HCl})$, переход в нижележащий горизонт постепенный.

$\mathrm{BM}_{\mathrm{Ca}}(10$ - 16 см) - черно-бурый, свежий, ореховато-комковатый, среднесуглинистый, рыхлый, пронизан корнями от мельчайших до крупных, присутствуют свежие и в разной степени разрушенные обломки карбонатных пород. Вскипает от $10 \% \mathrm{HCl}$, переход в нижележащий горизонт по увеличивающемуся количеству обломков карбонатных пород.

$\mathrm{C}_{\mathrm{Ca}}$ (16-150 см) - почвообразующая порода в виде дресвянистоглыбистого материала карбонатных пород с затеками темногумусового горизонта.

Второй компонент катены - абралиты карьера известняков с разработкой «в теле» средней части горы. Согласно [4], полезное ископаемое представлено линзой известняков мощностью $50-68$ м, залегающей среди песчаников и конгломератов с падением на северо-восток под углом около $50^{\circ}$. Горная порода вскипает от $10 \%$-ной $\mathrm{HCl}$.

Третий компонент катены - почвы: буроземы темные остаточнокарбонатные мелкие слабо скелетные, развитые на элювии мраморизированных известняков. Разрез 3 заложен в нижней части южного склона сопки. Основным растительным древесным компонентом является дуб монгольский. Заметно также участие Juglans mandshurica (ореха маньчжурского) и Acer ginnala (клена приречного). Из кустарников примерно в равной степени доминируют лещина разнолистная и леспедеца двуцветная. Травянистый покров на участке очень обильный. Морфологический профиль включает следующие генетические горизонты.

А0 (0 - 1 см $)$ - лесная подстилка из лесного опада.

$\mathrm{AU}(1$ - 16 см) - коричневато-серый, свежий, зернисто-мелкокомковатый, среднесуглинистый, рыхлый, не вскипает от $10 \% \mathrm{HCl}$, пронизан корнями диаметром от 0,1 до 0,5 мм, в почвенной массе присутствуют свежие и в разной степени разрушенные обломки песчаников и конгломератов, переход в нижележащий горизонт постепенный.

$\mathrm{BM}_{\mathrm{Ca}}(16$ - 61 см) - буро-рыжеватый, свежий, мелкокомковатый, среднесуглинистый, рыхлый, пронизан корнями от мельчайших до круп- 
ных, в почвенной массе присутствуют свежие и в разной степени разрушенные обломки песчаников и конгломератов, а также обломков карбонатных пород, вскипающих от $10 \% \mathrm{HCl}$, переход в нижележащий горизонт по увеличивающемуся количеству обломков карбонатных пород.

$\mathrm{C}_{\mathrm{Ca}}(61-110$ см) - почвообразующая порода в виде дресвянистоглыбистого материала карбонатных пород, перемешанных с песчаниками и конгломератами, вскипает от $10 \% \mathrm{HCl}$.

В работе обращено внимание на гранулометрический состав и физикомеханические свойства почв. Интерес к изучению физико-механических свойств почв обусловлен показательностью этих свойств как интегрального фактора, отражающего состав (минералогический, химический, гранулометрический), тип структурных связей, степень агрегированности и физическое состояние (плотность, степень водонасыщенности) [5].

1-й компонент катены - бурозёмы тёмные остаточно-карбонатные крайне мелкие средне скелетные. Данные почвы в темногумусовом горизонте и структурно-метаморфическом имеют небольшой показатель по плотности твердой фазы $\left(2,20-2,21\right.$ г/см $\left.{ }^{3}\right)$ в связи с хрящеватостью. По результатам гранулометрического и микроагрегатного анализов установлено, что бурозёмы тёмные остаточно-карбонатные крайне мелкие по профилю характеризуются как суглинки легкие крупнопылеватоопесчаненные в горизонте $\mathrm{AU}$ и $\mathrm{C}_{\mathrm{Ca}}$, в горизонте $\mathrm{BM}_{\mathrm{ca}}$ как суглинки легкие опесчаненно-крупнопылеватые. В верхнем темногумусовом горизонте и почвообразующей породе преобладают песчаные фракции, а в структурно-метаморфическом - фракция крупной пыли (табл. 1).

В микроагрегатном составе наблюдается превалирование макроагрегатов размером 1-0,25 (30\%); 0,25 - 0,05 (30\%); 0,05-0,01 (29\%) мм, а в процентном отношении выделяются фракции мелкого песка и крупной пыли. Илистая фракция не превышает $2 \%$.

В бурозёмах тёмных остаточно-карбонатных мелких слабоскелетных плотность твердой фазы во всех горизонтах морфологического профиля

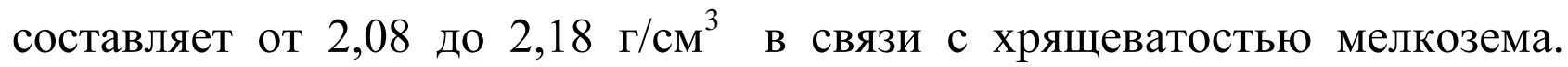
Эти почвы представлены суглинком лёгким песчано-крупно пылеватым в темногумусовом горизонте с утяжелением гранулометрического состава вниз по профилю до суглинка тяжелого опесчаненно-иловатого. Отмечается резкое увеличение по профилю илистой фракции с 5 \% в темногумусовом горизонте до $23 \%$ - в нижележащих. В микроагрегатном составе 
преобладают микроагрегаты с размером 0,25 - 0,05 (27 \%); 0,05 - 0,01 мм (40 \%). Преобладающими являются микроагрегаты крупной пыли.

Таблийа 1

\section{Гранулометрический и состав почв природно-техногенной катены «Голубиногорская»}

\begin{tabular}{|c|c|c|c|c|c|c|c|c|}
\hline \multirow{2}{*}{$\begin{array}{c}\text { Генетический } \\
\text { горизонт, } \\
\text { глубина, см }\end{array}$} & \multicolumn{6}{|c|}{$\begin{array}{c}\text { Гранулометрический состав почв (в \%), } \\
\text { величина фракций, мм }\end{array}$} & \multicolumn{2}{|c|}{$\begin{array}{l}\text { Сумма } \\
\text { частиц }\end{array}$} \\
\hline & $\begin{array}{c}1- \\
0,25\end{array}$ & $\begin{array}{c}0,25- \\
0,05\end{array}$ & $\begin{array}{c}0,05- \\
0,01\end{array}$ & $\begin{array}{l}0,01- \\
0,005\end{array}$ & $\begin{array}{c}0,005 \\
- \\
0,001\end{array}$ & $\begin{array}{c}< \\
0,001\end{array}$ & $<0,01$ & $>0,01$ \\
\hline \multicolumn{9}{|c|}{ Бурозем темный остаточно-карбонатный крайнемелкий среднескелетный } \\
\hline $\mathrm{AU}(0,5-10)$ & 23 & 29 & 20 & 7 & 10 & 11 & 28 & 72 \\
\hline $\begin{array}{c}\mathrm{BM}_{\mathrm{Ca}} \\
(10-16)\end{array}$ & 15 & 23 & 43 & 9 & 7 & 3 & 19 & 81 \\
\hline $\mathrm{C}_{\mathrm{Ca}}(16-150)$ & 36 & 22 & 18 & 6 & 5 & 13 & 24 & 76 \\
\hline \multicolumn{9}{|c|}{ Бурозем темный остаточно-карбонатный мелкий слабоскелетный } \\
\hline AU $(1-16)$ & 19 & 24 & 36 & 7 & 9 & 5 & 21 & 79 \\
\hline $\begin{array}{c}\mathrm{BM}_{\mathrm{Ca}} \\
(16-61)\end{array}$ & 19 & 21 & 19 & 7 & 11 & 23 & 41 & 59 \\
\hline $\mathrm{C}_{\mathrm{Ca}}(61-110)$ & 14 & 22 & 22 & 9 & 11 & 22 & 42 & 58 \\
\hline
\end{tabular}

По результатам гранулометрического и микроагрегатного анализов произведена оценка структуры, которая выявила водопрочную структуру всех горизонтов (табл. 2). Величина способности почв к оструктуриванию незначительная. Микроагрегированность всего профиля в основном низкая. В буроземах темных остаточно-карбонатных мелких слабо скелетных в горизонтах $\mathrm{BM}_{\mathrm{Ca}}$ и $\mathrm{C}_{\mathrm{Ca}}$ слабая, а противоэрозионная устойчивость, определенная по соотношению фактора структурности дисперсности к фактору дисперсности структурности средняя. Противоэрозионная устойчивость бурозёмов тёмных остаточно-карбонатных крайнемелких среднескелетных низкая.

По физико-механическим свойствам получены следующие показатели, при которых проявляются пластические свойства данных почв: значения влажности, соответствующие нижнему пределу пластичности, находятся в интервале от 71 до $76 \%$, то есть изученные почвы пластичны (табл. 3). Граница в скатывание в шнур имеет несущественный интервал 
от 21 до 27 \%. При влажности, превышающей нижний предел пластичности, почва оказывает слабое сопротивление механическому воздействию.

Таблийа 2

\section{Показатели способности к оструктуриванию почв}

природно-техногенной катены «Голубиногорская»

\begin{tabular}{|c|c|c|c|c|}
\hline $\begin{array}{l}\text { Гори- } \\
\text { зонт, } \\
\text { глуби- } \\
\text { на, см }\end{array}$ & $\begin{array}{l}\text { Фактор дис- } \\
\text { персности }\end{array}$ & $\begin{array}{c}\text { Степень агрегиро- } \\
\text { ванности }\end{array}$ & $\begin{array}{c}\text { Фактор } \\
\text { структурности }\end{array}$ & $\begin{array}{c}\text { Противоэро- } \\
\text { зионная } \\
\text { стойкость }\end{array}$ \\
\hline \multicolumn{5}{|c|}{ Бурозём тёмный остаточно-карбонатный крайне мелко средне скелетный } \\
\hline $\begin{array}{c}\mathrm{AU} \\
0,5-10\end{array}$ & $\begin{array}{l}9 \text { - структура } \\
\text { водопрочная }\end{array}$ & $\begin{array}{c}13- \\
\text { микроагрегирован } \\
\text { ность низкая }\end{array}$ & $\begin{array}{c}12 \text { - способность } \\
\text { к оструктуриванию } \\
\text { незначительная }\end{array}$ & $1,4-$ низкая \\
\hline $\begin{array}{l}\mathrm{BM}_{\mathrm{Ca}} \\
10-16\end{array}$ & $\begin{array}{c}0 \text { - структура } \\
\text { водопрочная }\end{array}$ & $\begin{array}{c}3- \\
\text { микроагрегирован } \\
\text { ность низкая }\end{array}$ & $\begin{array}{c}18 \text { - способность } \\
\text { к оструктуриванию } \\
\text { незначительная }\end{array}$ & 0 - низкая \\
\hline $\begin{array}{c}\mathrm{C}_{\mathrm{Ca}} \\
16-150\end{array}$ & $\begin{array}{l}0 \text { - структура } \\
\text { водопрочная }\end{array}$ & $\begin{array}{c}13 \text { - микроагреги- } \\
\text { рован } \\
\text { ность низкая }\end{array}$ & $\begin{array}{c}13 \text { - способность } \\
\text { к оструктуриванию } \\
\text { незначительная }\end{array}$ & 0 - низкая \\
\hline \multicolumn{5}{|c|}{ Бурозём тёмный остаточно-карбонатный мелкий слабо скелетный } \\
\hline $\begin{array}{c}\mathrm{AU} \\
1-16\end{array}$ & $\begin{array}{c}20 \text { - структура } \\
\text { достаточно во- } \\
\text { допрочная }\end{array}$ & $\begin{array}{c}19 \text { - микроагреги- } \\
\text { рован } \\
\text { ность низкая }\end{array}$ & $\begin{array}{c}19 \text { - способность } \\
\text { к оструктуриванию } \\
\text { незначительная }\end{array}$ & 1,0 - низкая \\
\hline $\begin{array}{l}\mathrm{BM}_{\mathrm{Ca}} \\
16-61\end{array}$ & $\begin{array}{l}9 \text { - структура } \\
\text { водопрочная }\end{array}$ & $\begin{array}{c}38 \text { - микроагреги- } \\
\text { рован } \\
\text { ность слабая }\end{array}$ & $\begin{array}{c}27 \text { - способность } \\
\text { к оструктуриванию } \\
\text { незначительная }\end{array}$ & 3 - средняя \\
\hline $\begin{array}{c}\mathrm{C}_{\mathrm{Ca}} \\
61-110\end{array}$ & $\begin{array}{l}5 \text { - структура } \\
\text { водопрочная }\end{array}$ & $\begin{array}{c}43 \text { - микроагреги- } \\
\text { рован } \\
\text { ность слабая }\end{array}$ & $\begin{array}{c}27 \text { - способность } \\
\text { к оструктуриванию } \\
\text { незначительная }\end{array}$ & $5,4-$ средняя \\
\hline
\end{tabular}

В темногумусовом горизонте такой границей является влажность $76 \%$, в нижнем - 30\%. Число пластичности, находится в интервале от 29 до 9.

Бурозёмы тёмные остаточно-карбонатные мелкие слабоскелетные обладают незначительной способностью к оструктуриванию при водопрочной и достаточно водопрочной структуре. Противоэрозионная стойкость почв по значению отношений фактора структурности к фактору дисперсности варьирует от низкой до средней. По физико-механическим свойствам (табл.3), почвы находятся в следующем состоянии: граница 
скатывания почвы в шнур с нешироким интервалом от 21 до $30 \%$. При влажности, превышающей нижний предел пластичности, почва оказывает слабое сопротивление механическому воздействию. В темногумусовом горизонте такой границей является влажность 71 \%, а в нижележащем - $50 \%$. Число пластичности в верхних горизонтах находится в интервале от 29 до 30, что позволяет причислить почвы к тяжелым и соответствует данным гранулометрического состава.

Таблица 3

\section{Физико-механические свойства почв природно-техногенной катены} «Голубиногорская»

\begin{tabular}{|c|c|c|c|c|c|c|}
\hline $\begin{array}{c}\text { Гори- } \\
\text { зонт, } \\
\text { глуби- } \\
\text { на, } \\
\text { см }\end{array}$ & $\begin{array}{c}\text { Граница } \\
\text { клейко- } \\
\text { сти }\end{array}$ & $\begin{array}{l}\text { Нижний } \\
\text { предел } \\
\text { текуче- } \\
\text { сти }\end{array}$ & $\begin{array}{c}\text { Верх- } \\
\text { ний } \\
\text { предел } \\
\text { текуче- } \\
\text { сти }\end{array}$ & $\begin{array}{c}\text { Граница } \\
\text { скатыва- } \\
\text { ния в } \\
\text { шнур }\end{array}$ & $\begin{array}{c}\text { Число } \\
\text { пластич- } \\
\text { ности }\end{array}$ & \multirow[t]{2}{*}{$\begin{array}{c}\text { Гранулометриче- } \\
\text { ский состав } \\
\text { по пластичности }\end{array}$} \\
\hline \multirow{2}{*}{\multicolumn{7}{|c|}{ Бvрозём тёмный остаточно-карбонатный крайнемелкий срелнескелетный }} \\
\hline & & & & & & \\
\hline $\begin{array}{c}\text { AU } \\
0,5-10\end{array}$ & 46 & 61 & 76 & 27 & 29 & глины \\
\hline $\begin{array}{c}\mathrm{BM}_{\mathrm{Ca}} \\
10-16\end{array}$ & 30 & 56 & 71 & 21 & 25 & глины \\
\hline $\begin{array}{c}\mathrm{C}_{\mathrm{Ca}} \\
16- \\
150\end{array}$ & 21 & 27 & 30 & 27 & 9 & суглинки \\
\hline \multicolumn{7}{|c|}{ Бурозём тёмный остаточно-карбонатный мелкий слабоскелетный } \\
\hline $\begin{array}{c}\mathrm{AU} \\
1-16\end{array}$ & 46 & 60 & 71 & 30 & 30 & глины \\
\hline $\begin{array}{c}\mathrm{BM}_{\mathrm{Ca}} \\
16-61\end{array}$ & 34 & 45 & 50 & 22 & 23 & глины \\
\hline $\begin{array}{c}\mathrm{C}_{\mathrm{Ca}} \\
61- \\
110\end{array}$ & 37 & 39 & 48 & 27 & 12 & глины \\
\hline
\end{tabular}

Исследования по установлению допустимой не размывающей скорости водного потока показали, что для начального момента отрыва почвенных частиц от почвенной поверхности потребуется скорость от 0,240 - 


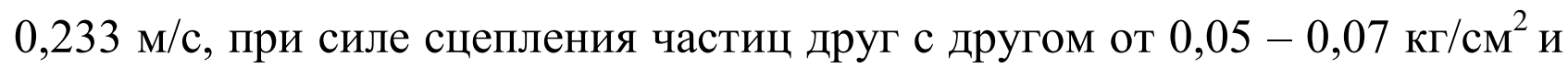
нормативной усталостной прочности на разрыв $0,0013-0,0019 \kappa г / \mathrm{cm}^{2}$.

В бурозёмах тёмных остаточно-карбонатных мелких слабоскелетных, для начального момента отрыва почвенных частиц от почвенной поверхности свойственны близкие показатели к показателям скорости, силе сцепления частиц и нормативной усталостной прочности на разрыв к бурозёмам тёмным остаточно-карбонатным крайнемелким и средним скелетным (от 0,236 до

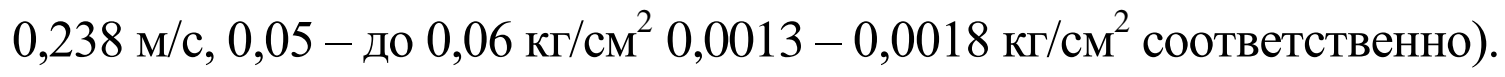

Физико-химические свойства почв катены. Первый компонент катены - бурозёмы тёмные остаточно-карбонатные крайнемелкие среднескелетные. В темногумусовом горизонте почв, как и во всем профиле, реакция среды слабощелочная $\left(\mathrm{pH}_{\mathrm{c}} 7,37 ; \mathrm{pH}_{\mathrm{B}} 8,06\right)$. По содержанию гумуса в темногумусовом горизонте почвы относятся к тучным (9,57 \%). В структурно-метаморфическом горизонте количество гумуса увеличивается до 23,39 \%, а в почвообразующей породе снижается до 0,72 \%.

В буроземах темных остаточно-карбонатных мелких слабоскелетных темногумусовых, в структурно-метаморфическом горизонте и почвообразующей породе этих почв реакция слабокислая $\left(\mathrm{pH}_{\mathrm{c}} 6,00\right)$. Актуальная кислотность слабощелочная $\left(\mathrm{pH}_{\mathrm{B}} 7,53\right)$. Изученные почвы обладают высокогумусированным горизонтом, в нижележащих содержание гумуса снижается с 9,93 до 1,36-1,28\%.

Номенклатура и классификация почв катень

Первый компонент катены - бурозёмы тёмные остаточнокарбонатные крайнемелкие среднескелетные. Данные почвы относятся к стволу постлитогенных почв [11]. Основные подтипы выделяются по признакам оподзаливания, оглеения и остаточной карбонатности. Остаточнокарбонатные имеют следующий морфологический профиль $\mathrm{AU}-\mathrm{BM}_{\mathrm{Ca}}-\mathrm{C}_{\mathrm{Ca}}$. Мелкозем преимущественно выщелочен от карбонатов. Педогенные карбонаты в виде новообразований отсутствуют. Формируются на элюводелювии карбонатных пород.

Для выделения видов с учетом мощности гумусовых горизонтов и градаций по [11] изученные почвы относятся к крайнемелким, по глубине залегания карбонатов - к глубоко карбонатным, по содержанию гумуса в гумусовом горизонте к тучным.

Выделение почв на уровне разновидностей учитывает их гранулометрический состав и скелетность. Изученные почвы относятся к легкосу- 
глинистым и к среднескелетным. Судя по проникновению корней древесной растительности вглубь, имеют глубоко развитый профиль. По генетическому типу почвообразующих пород выделен разряд почв на элювии бурозёмы тёмные остаточно-карбонатные крайнемелкие среднескелетные, развитые на элювии.

Третий компоненты катены - бурозёмы тёмные остаточно-карбонатные мелкие слабоскелетные. Почвы относятся к стволу постлитогенных почв, к отделу - структурно-метаморфические почвы, к типу - буроземы темные. По мощности гумусового горизонта (см): мелкие $(10-20$ см). По содержанию гумуса в гумусовом горизонте - тучные. По гранулометрическому составу выделены разновидности: легкосуглинистые, тяжелосуглинистые; по степени скелетности - слабоскелетные; по мощности мелкозёмистой толщи - с глубоко развитым профилем. По генетическому типу почвообразующих пород отнесены к разряду почв - на элювии.

Исследованием механических и физико-химических свойств почв природно-техногенной почвенной катены «Голубиногорская» установлено:

1. Бурозёмы тёмные остаточно-карбонатные крайнемелкие среднескелетные как и бурозёмы тёмные остаточно-карбонатные мелкие слабоскелетные в темногумусовом горизонте и структурно-метаморфическом

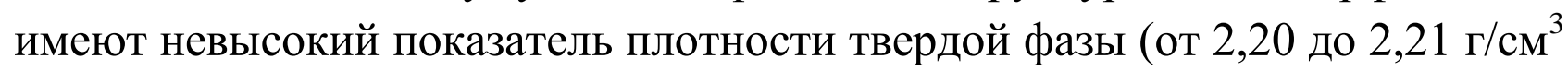
и от 2,08 до 2,18 г/см ${ }^{3}$ в в связи с хрящеватостью мелкозема.

2. Бурозёмы тёмные остаточно-карбонатные крайнемелкие по всему профилю характеризуются как суглинки легкие крупнопылеватоопесчаненные. В верхнем темногумусовом горизонте и почвообразующей породе преобладают песчаные фракции, а в структурно-метаморфическом фракция крупной пыли. Темногумусовый горизонт бурозёмов тёмных остаточно-карбонатных мелких слабоскелетных характеризуется как суглинок лёгкий песчано-крупнопылеватый с утяжелением вниз по профилю гранулометрического состава до суглинка тяжелого опесчаненно-иловатого. Отмечается резкое увеличение по профилю илистой фракции с 5 \% в темногумусовом горизонте до $23 \%$ - в нижележащих.

3. Для всех горизонтов исследуемых почв свойственна водопрочная структура, незначительная способность почв к оструктуриванию и в основном низкая противоэрозионная устойчивость. 
4. Почвы пластичны. По показателям влажности, соответствующему верхнему пределу текучести, бурозёмы тёмные остаточно-карбонатных крайнемелкие среднескелетные характеризуются большими показателями от 71 до 76 \%. Гранулометрический состав по профилю изменяется от глин до суглинков. В бурозёмах тёмных остаточно-карбонатных мелких слабоскелетных показатели влажности более низкие - от 71 до 50 \%, гранулометрический состав по профили не изменяется (глины).

5. Результаты исследований по установлению допустимой не размывающей скорости водного потока показали, что в бурозёмах тёмных остаточно-карбонатных крайнемелких среднескелетных и слабоскелетных для начального момента отрыва почвенных частиц от почвенной поверхности потребуется сравнительно близкая скорость от 0,240 до $0,233 \mathrm{~m} / \mathrm{c}$ и от 0,236 до $0,238 \mathrm{~m} / \mathrm{c}$, при силе сцепления частиц друг с другом от 0,05 до 0,07 кг $/ \mathrm{cm}^{2}$ и от 0,05 до 0,06 кг/см при нормативной усталостной прочно-

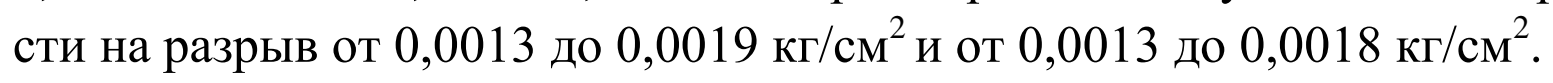

6. Исследуемые почвы характеризуются слабощелочной и близкой к нейтральной реакции среды. Поверхностные горизонты почв высокогумусированы. Вниз по профилю содержание гумуса постепенно снижается.

7. Установлена классификационная принадлежность исследуемых почв к типам, подтипам, разрядам и разновидностям согласно градациям классификации почв 2004 года.

\section{Литература}

1. Аринушкина Е.В. Руководство по химическому анализу почв. М.: Изд-во МГУ, 1961. 491 с.

2. Вадюнина А.Ф., Корчагина З.А. Методы исследования физических свойств почв и грунтов: учебное пособие для студентов вузов. Изд. 2-е. М., «Высшая школа», 1973. 400 с.

3. Воронин, А.Д., Кузнецов, М.С. Опыт оценки противоэрозионной стойкости почв // Эрозия почв русловые процессы. Вып. 1. М., 1970. C. 99-115.

4. Геология СССР. Том XXXII. Приморский край. Полезные ископаемые. М., «Недра», 1974. 156 с.

5. Горькова И.М. Структурные и деформационные особенности осадочных пород различной степени уплотнения и литификации. М.: Наука, 1965. 215 с. 
6. Дербенцева А.М., Дудкин Р.В., Брикманс А.В., Семаль В.А., Майорова Л.П., Матвеенко Т.И., Нестерова О.В., Рыбачук Н.А., Курочкина И.А. Природная почвенная катена Барабашской свиты «Второй известковый ключ»: факторы почвообразования и свойства компонентов. Владивосток: Изд-во Дальневост. ун-та, 2015. 74 с.

7. Дудкин Р.В., Дербенцева А.М., Скирина И.Ф., Майорова Л.П., Матвеенко Т.И., Черенцова А.А., Горобец К.В., Нестерова О.В., Брикманс А.В., Рыбачук Н.А., Курочкина И.А., Семаль В.А., Кузнецова Е.А., Александров М.Н. Лишайники-эпилиты и растительный покров почв, развитых на карбонатных отложениях «Екатериновского кряжа» Владивосток: Издво Дальневост. ун-та, 2015. 84 с.

8. Иванов Г.И. Почвообразование на юге Дальнего Востока. М.: Наука, 1976. 199 с.

9. Ивлев А.М. Географические закономерности формирования почвенного покрова в зоне перехода от континента к океану //Почвы островов и океанических регионов. Материалы XIV Тихоокеанского научного конгресса. 1982 .С. 19-26

10. Качинский Н.А. Механический и микроагрегатный состав почвы, методы его изучения. - М.: Академии наук СССР, 1958. 192 с.

11. Классификация и диагностика почв России. Смоленск: Ойкумена, 2004. 342 с.

12. Крейда Н.А. Почвы хвойно-широколиственных и широколиственных лесов Приморского края // Учен. зап. Дальневост. ун-та, т. ХХУ11. Ч.2. Владивосток, 1970. 228 с.

13. Мирцхулава Ц.Е. Инженерные методы расчета и прогноза водной эрозии. М.: Колос, 1970. 239 с.

14. Указания по определению допустимых (неразмывающих) скоростей водного потока для различных грунтов и облицовок. М., 1977. 34 с.

15. Цытович Н.А. Механика грунтов. М.: Высшая школа, 1973. 280 с. 